\title{
Environmental Justice and Regional Political Ecology converge in the other California
}

\author{
Jonathan K. London ${ }^{1}$ \\ University of California, Davis, USA
}

\begin{abstract}
This article illuminates the value of the concept of the region in political ecology and environmental justice studies by presenting three arguments about the role of regions in environmental justice social movements engaged in climate change mitigation in California's San Joaquin Valley. First, regional planning agencies and environmental justice advocates are engaged in conflicts over not only the content of regional climate change plans, but the very definitions of region and the authority used to put these regional visions into action. Second, regional organizing provides environmental justice movements with new opportunities to address regional economic patterns and to negotiate with regional planning agencies, both of which influence local manifestations of environmental injustice. Third, regional strategies raise significant dilemmas for these movements as they try to sustain engagement across extensive spatial territories and engage with a broad set of policy and economic protagonists. Together, this analysis demonstrates that a dynamic approach to regions, regionalism, and regionalization can assist political ecology and environmental justice scholars in their common aim of understanding the co-production of social and environmental inequity and collective action to change it.
\end{abstract}

Key Words: Environmental justice, regional political ecology, climate change mitigation, regional planning, rural community development

\section{Résumé}

Cet article met en lumière l'importance du concept de région dans les domaines de l'écologie politique et de la justice environnementale, en présentant trois arguments relatifs au rôle des régions dans le cadre de mouvements sociaux de défense de la justice environnementale agissant contre le changement climatique dans la vallée de San Joaquin en Californie. Premièrement, les agences de planification régionale et les défenseurs de la justice environnementale sont en conflit, non seulement sur le contenu des plans régionaux de changement climatique, mais aussi sur la définition même de région et sur les compétences exercées par les agences mettant ces visons régionales en action. Deuxièmement, en s'organisant au niveau régional, les mouvements de défense de la justice environnementale développent de nouvelles opportunités de questionnements des orientations de l'économie régionale et de négociations avec les agences de planification régionale, qui dans les deux cas ont un impact sur les effets locaux de l'injustice environnementale. Troisièmement, les stratégies régionales de ces mouvements les mettent face à d'importants dilemmes alors qu'ils essayent de maintenir leur engagement sur de larges territoires et coopèrent avec une grande variété d'acteurs économiques et politiques. De manière globale, cette analyse démontre qu'une approche dynamique aux concepts de région, de régionalisme et de régionalisation peut aider les chercheurs en écologie politique et en justice environnementale dans leur but commun de compréhension de la coproduction des inégalités sociales et environnementales.

Mots Clés: Justice environnementale, action contre le changement climatique, planification régional

\footnotetext{
${ }^{1}$ Dr. Jonathan K. London, Associate Professor, Community and Regional Development, Department of Human Ecology, and Director, Center for Regional Change, University of California Davis, Davis, CA 95616 USA. Email: jklondon "at" ucdavis.edu. I would like to thank the National Institute for Food and Agriculture and the Resources Legacy Fund for partial funding for this project, my UC Davis collaborators Catherine Garoupa White, Dana Rowangould, Alex Karner and Chris Benner, and our many community partners in the regional equity movements for their support. Thank you to Colleen Hiner and Innisfree Mckinnon for organizing this Special Section and to the three anonymous reviewers from the Journal of Political Ecology for offering valuable additional insights. This is the fifth article in Innisfree, McKinnon and Colleen Hiner (eds.) 2016. "(Re)considering regional political ecology?", Special Section of the Journal of Political Ecology 23: 115-203.
} 


\section{Resumen}

Este artículo discute la importancia del concepto de región en la ecología política y los estudios sobre justicia ambiental, a través de la presentación de tres argumentos sobre el papel de las regiones en movimientos sociales en el Valle de San Joaquin, California, que están luchando por la mitigación del cambio climático. Primero, agencias del estado y defensores de la justicia ambiental están en conflicto no solo sobre el contenido de los planes para combatir al cambio climático en nivel regional, sino sobre la definición de region y la autoridad utilizada para poner estas visiones regionales en acción. Segundo, organizando en nivel regional da nuevas oportunidades a los movimientos por justicia ambiental, para trabajar sobre padrones económicos regionales y negociar con agencias de planeación regional. Tercero, el uso de estrategias regionales presenta dilemas importantes para estos movimientos en el trabajo de sostener la iniciativa en espacios y poblaciones diversos, así como confrontar un abanico variado de actores económicos y políticos. Juntos, los tres argumentos muestran que un acercamiento flexible y dinamico a los conceptos de region, regionalismo y regionalización, podría apoyar a los investigadores utilizando enfoques de la ecologia politica y la justicia ambiental en su objetivo mutuo de entender la coproducción de la desigualdad socioambiental y la acción colectivo necesario para cambiarla.

Palabras claves: Justicia ambiental, ecología política regional, mitigación del cambio climático, planeación regional, desarrollo rural comunitario

\section{Introduction}

The concept of the region has occupied a central but unsettled place in political ecology and environmental justice scholarship. This unsettled quality, I suggest, derives from the complex, contradictory, and contested ways that regions are defined across varied social, cultural, economic, biophysical, political, and other dimensions. Debates over whether regions should be approached analytically as things, processes, identities or some combination of these have significant implications for the ways in which this concept can facilitate or impede the shared project of political ecology and environmental justice studies' to explain the relationships between social and environmental inequities. Therefore, scholars in both fields - or those, such as this author, who draw from the two together-should have a strong interest in developing a definition of regions equal to this task.

In this article, I present a case study of climate change mitigation policy, planning, and advocacy in the San Joaquin Valley - sometimes called the "Other California" (Haslam 1994) for its deep and persistent poverty, in contrast to the state's better-known and wealthy coastal regions. I use this context to develop a working concept of regions that can assist political ecology and environmental justice scholars and practitioners in their common aims. In particular, I examine how conflicts between environmental justice advocates and government agencies engaged in climate change issues revolve around competing definitions and ways to operationalize these definitions in shaping regional land use, housing, and transportation plans. In so doing I also seek to highlight the contributions that a regionally-focused environmental justice scholarship can make, and to respond to Neumann's call for "a more universal and theoretically robust [Regional Political Ecology]" (2010: 372).

In his review of the rise and development of political ecology, Neumann observes that the term region is central to the field's foundational texts (Blaikie and Brookfield 1987). While early political ecology scholarship offered compelling explanations of environmental, political, and economic inequities, Neumann observes that it also tended to reify regions as things, transformed by the power of "external forces" instead of "relational, historicized, contextualized, and dynamic" entities (2010: 369-370). Neumann argues that these latter qualities ought to serve as the basis for a robust regional political ecology.

Two of the foundational texts in environmental justice scholarship also adopt a regional approach. Pulido (1996) situates her historical narratives of conflict over Hispano grazing rights in New Mexico, pesticide exposures, and labor unrest in California's San Joaquin Valley, in the broadly defined 'Southwest.' Bullard calls out the legacies of violence, segregation, and structural racism in the American South as leading to the overburdening of African American communities with environmental hazards through a process that he calls "Dumping in Dixie" (1990/2000). While compelling, Pulido's (1996) and Bullard's (1990/2000) portrayals of regions also suffer from some of the shortcomings seen in early political ecology scholarship. 
Both scholars bound and name an area as the setting in which environmental injustices are produced and contested. Yet they do not examine the ways in which these bounding and naming processes are themselves expressions of political and economic power by states, capital, and social actors with material effects on the health of marginalized people and places.

Since the publication of Pulido's and Bullard's seminal works, environmental justice scholars have focused considerable attention on the ways in which environmental injustice is produced and contested at multiple geographic and jurisdictional scales. These cut across what can be termed regional, national, international and global levels (Bickerstaff and Agyeman 2009, Bulkeley 2005, Bulkeley et al. 2013, Faber 2007, Harrison 2011b, Holifield 2012, Ikeme 2003, Pellow 2007, Sze et al. 2009). These environmental justice scholars situate this multi-scalar analysis of environmental injustices in the imperatives and the crises of the neoliberal capitalist economy and state. These theoretical projects resonate with the work of scholars engaged in rethinking the place of regions in political ecology (e.g. Black 1990; Walsh 2004) that considers the historically contingent processes of regions in the making (Neumann 2010). Bringing environmental justice and political ecology scholarship into dialogue over how to define regions can, I argue, yield insights valuable to both fields.

Political ecology and environmental justice scholarship on regions draw on similar insights from critical human geography, and in particular, New Regional Geography that calls out the distinct, but interdependent notions of regions (things), regionalism (ideologies/meanings), and regionalization (processes) (Paasi 1991, 2003). Regions can be understood as bounded territories (often, but not always at the sub-state level) that can function as units of governance, zones of economic activity, social networks, and bases of cultural identities. Regionalisms are ideologies that represent and naturalize regions as the proper scale for understanding and acting upon political, economic, social and cultural projects. These ideologies are often represented through various and sometimes competing cartographic technologies and artifacts (Painter 2008). Regionalization describes the historically contingent and contested political, economic, and social processes through which regions are continuously produced and reproduced (Jonas 2013, Neumann 2010, Pred 1984, Paasi 1991, 2003, Pred 1984). Regions, regionalism, and regionalization must be viewed as expressions of power serving the interests of some social actors over others, and through which state, capital and social movement actors pursue often divergent political and social agendas (Jones and MacLeod 2004, Paasi 2003, Benner and Pastor 2011). Regionalization can occur from both "above", through the re-scaling of formal state institutions, and from "below", through civic discourse, identify formation, and insurgent regionalism movements. The misalignment of these processes and the resulting incoherence of regions often results in state-social movement conflicts (Jones 2001, 2004, Jones and MacLeod 2004, Paasi 1986). Finally, regions must be seen - not as places apart - but as embedded within and constitutive of local, state, national, global territories and processes (Jonas and Pincetl 2006, Painter 2002).

Political ecology and environmental justice scholars both apply these conceptual frameworks of regions to their distinct but complementary analytical projects. In particular, I argue, political ecology scholars approach the concepts of regions to help understand how state and capital actors produce inequitable social and environmental outcomes. Environmental justice scholars in the U.S., on the other hand, focus on the particular impact of these regional processes on low-income people and people of color, and how they mobilize to challenge or negotiate these outcomes. Political ecology can therefore provide environmental scholars with robust theoretical approaches to capital's complex logics while environmental justice studies can help ground political ecology in the lived experiences of those most affected and most invested in working to change these re-envision and reshape these political and economic systems.

\section{Methods and organization}

In what follows, I apply these understandings of regions, regionalism and regionalization from the two perspectives to a case study of environmental and social justice movements in California's San Joaquin Valley. These movements are engaged in contesting climate change planning and policy using strategies that negotiate with existing regional institutions, and seek to articulate and enact new visions for a more equitable region. I draw on three years of participant observation research as part of a university team providing technical assistance to environmental justice movement campaigns in the arena of regional transportation, 
housing and land use policies. I also draw on a set of semi-structured interviews with 10 key policy, planning, and advocacy leaders, as well as an analysis of archival documents (campaign materials, regional plans, and media accounts). ${ }^{2}$ I make the following four arguments:

1. Environmental justice movements and planning agencies are engaging in conflicts over not only the content of regional plans for climate change mitigation, but the very definitions of region, and the authority used to put these regional plans into institutional form.

2. Regional level organizing provides environmental justice movements with new opportunities to address regional economic patterns and to negotiate with regional planning agencies, both of which influence local manifestations of environmental injustice.

3. Regional strategies also provoke significant dilemmas for environmental justice movements, such as the challenge of sustaining engagement across extensive territories, encompassing broad issue agendas, requiring broad alliances, demanding new sets of technical expertise, and requiring engagement with a broader set of policy and economic actors.

4. Understanding the central place of regions in social movement and state actions on climate change mitigation can help inform a robust field of regional political ecology and environmental justice studies.

\section{Placing the San Joaquin Valley Region}

The San Joaquin Valley is considered to be one of California's iconic regions. It is the agricultural heartland of the Golden State, the deep well of its oil and gas production, and its major north-south transportation artery. But the 250-mile $(402 \mathrm{~km}$ ) long valley inhabited by 4 million residents (over half of whom are Latino and with significant immigrant populations from South and Southeast Asia, along with longstanding African American communities) is also rife with conflict. Extreme environmental, social, and health injustices are often hidden in plain sight (Goldschmidt 1947, Mitchell 1996) earning it the moniker of "the Other California" (Haslam 1994). It is known for its conservative political climate that favors an ideology of local (vs. state or federal) government and control, and it is dominated by agricultural, petro-chemical and land development industries. Finally, it is infamous for its institutionalized racism, which is often reflected in harsh attitudes toward immigrants and people of color. These factors, along with extreme inequality and crushing poverty, make the San Joaquin Valley a profoundly challenging context for social movement organizing (Fujimoto 2010, London, Huang, and Zagofsky 2011, London et al. 2013, Nash 2006, Pulido 1996, Pulido and Peña 1998).

Faced with this political and economic climate, for decades, environmental justice movements have struggled to address the Valley's racialized concentration of environmental hazards, such as agricultural pesticide use, hazardous waste facilities, polluted air and drinking water, and limited access to environmental amenities, especially as they affect communities of predominantly low-income people and people of color (Cole and Foster 2001, Huang and London 2012, London, Huang, and Zagofsky 2011, Nash 2006, Perkins 2012, Pulido 1996).Traditionally, environmental justice movements in the San Joaquin Valley have focused on reducing the disproportionate burden of environmental hazards on these communities. Lately, however, they have joined similar environmental justice movements in other areas in launching campaigns to increase the presence and access to environmental resources and opportunities (such as nutritious food, green spaces, living wage jobs, affordable housing, public transit (Anguelovski 2013, Jermé and Wakefield 2013, Saxton 2015). Coinciding with this shift in topical focus, environmental justice movements are increasing their engagement in regional and statewide land use, transportation, and housing planning.

\footnotetext{
${ }^{2}$ My hybrid role as a researcher and an actor in the case study affords me with a unique, but complicated vantage point on the events described here. While I cannot claim impartiality, I hold that such an approach can enhance the relevance of the research to social change; engaged scholarship is also subject to iterative cycles of action and reflection, which can offer deeper insight into social and political processes (Balazs and Morello-Frosch 2013, London et al. 2011, Morello-Frosch et al. 2005).
} 


\section{Environmental justice and regional planning policies}

Regional approaches to environmental management and social movement organizing is hardly new to California or the San Joaquin Valley. The formation of regional air pollution districts (starting in the San Francisco Bay Area and Los Angeles basin in the 1970s and in the early 1990s in the San Joaquin Valley), and regional water quality control boards in the the 1970s amongst others, reflects the California legislature's drive for cohesive and legible territories that would provide for "seeing like a state" (Scott 1998). It also resulted from social movements that sought to address environmental issues that crossed jurisdictional boundaries. While ambitious, these regionalization projects have encountered significant push back from local-control oriented governments and capitalist actors opposed to state regulation. Referring to the local control capture of regional growth management in California, Pincetl (1994) recounted a "history of failure."

The problematic terrain for regionalization in the San Joaquin Valley is partially a matter of jurisdictional fragmentation. Unlike their counterparts in the San Francisco, Sacramento, and Los Angeles areas, all of which have multi-county Metropolitan Planning Organizations (MPOs) to manage regional transportation planning, the eight counties in the San Joaquin Valley have instead opted to form county-scale Councils of Governments (COGs) instead of adapting a multi-county form of governance. These COGs generally reflect the conservative politics of their local jurisdictions, making it hard for advocates and even equity-minded planners to develop regional plans that reflect an environmental justice orientation. Furthermore, because land use authority is vested solely in city and county governments, the regional plans provide only guidance and financial incentives, but not enforceable mandates for their implementation. As a result in the case of the San Joaquin Valley, regional approaches to environmental policy and planning have collided with a "local control" political culture in which cities and counties resist state and federal environmental mandates (Andrews and Fairfax 1983, Lubell, Feiock and Handy 2009).

In the face of this contested regionalization, environmental justice and social activists have been some of the few consistent proponents of regional approaches to governance. For example, in an attempt to counter the political power of the agricultural, petro-chemical and land development industries on county government, environmental organizations in the 1970s and 1980s were joined by emerging environmental justice movements in the late 1980s and early 1990s. They were eventually backed by the state legislature, and pressed successfully for the formation of the San Joaquin Valley Air Pollution Control District that combined the eight county-scale districts into one. While this regional district did provide a single target for environmental justice advocates, not surprisingly the power of industry and sympathetic local governments has been hard to dislodge. Undeterred, environmental justice advocates have formed regional coalitions such as the 70-member Central Valley Air Quality Coalition and several regional water quality coalitions to address cross-boundary pollution. In the process, they have developed relatively cohesive regional identities that are not merely tactical, but that are maintained between campaigns.

Layered on this uneven history of regional governance and social action in the San Joaquin Valley, a new round of regionalization has been prompted by the introduction of state and federal mandates on cities and counties related to climate change mitigation and adaptation. In particular, this shift has been triggered by the passage of California's Sustainable Communities and Climate Protection Act of 2008 (Senate Bill 375). SB 375 is the primary mechanism to meet California's greenhouse gas reduction goals (reducing emissions to 1990 levels by 2020). ${ }^{3}$ Under SB 375, each federally designated MPO or COG in California is assigned a target for reducing automobile and light truck traffic (the single largest source of greenhouse gases) in its jurisdictional region. The plans drawn up to meet these goals are known as a sustainable communities strategy, or SCS. SCSs must include comprehensive land use, transportation, and housing plans and policies designed to build regions less reliant on private automobile use, thereby reducing its climate change footprint (Darakjian 2007). Under SB 375, MPOs have to consider not only the allocation of transportation funding across their member jurisdictions, but must also weigh how comprehensive planning could reduce the greenhouse gas emissions for their metropolitan territories as a whole. Thus, SB 375 represents a clear move toward the rescaling of greenhouse reduction strategies, away from the local, toward the regional. To take this

\footnotetext{
${ }^{3}$ These targets were set by Assembly Bill 32, the California Global Warming Solutions Act of 2006. [Accessed January
} 18, 2015.] http://www.arb.ca.gov/cc/ab32/ab32.htm. 
analysis one step further, we see a cascading set of goals and strategies played out across time and space: the global goal of mitigating climate change is translated into a state-wide mandate, which is to be executed regionally and implemented locally. However, this process is not strictly a linear 'down-scaling.' Rather, as we shall see, it invites a fluid and often contested reconfiguration of the relationships between multiple scales of governance (Bulkeley 2005, Heynen 2003) and to some extent it has produced hybrid forms and scales of governance that link local, regional, and state institutions in new ways (Cohen and McCarthy 2015).

\section{Regional dilemmas for environmental justice movements}

Environmental justice movements in the San Joaquin Valley, as elsewhere, have long advocated for environmental regulation that recognizes and intervenes in the co-production of environmental and social inequity and its influence on human health (Huang and London 2012b, Krieg and Faber 2004, Sadd et al. 2011). To them, SB 375 offered clear benefits. Under the SB 375 rubric, environmental justice advocates hoped they could begin to address a scalar mismatch between regional decision-making and local sites of impact (Kurtz 2003, Towers 2000). Yet many environmental justice movement leaders who have struggled for decades to pass strict regional air pollution control plans expressed frustration that even their rare policy successes could not help them address regional land use, transportation, housing and employment patterns that contributed to the Valley's air pollution that affected their health. That is, SB 375 provided a new policy vehicle for environmental justice advocates' longstanding push for regionalization of environmental policy and planning. One environmental justice activist described this analysis of regional land use patterns and and how it shaped their resulting organizing approach this way:

I think that we always knew land use was a problem, but for a while it just seemed so overwhelming, and out of reach to make any difference in decisions about land use planning that we didn't engage in it...I think a lot of things happened to shift everybody to working on that, of course SB375 passing... I think SB 375 created an opportunity to touch a lot of the opportunities we cared about, like air quality (Personal communication with author, 2013).

A public health-oriented board member of the San Joaquin Valley Air Pollution Control Board and the California Air Resources Board (the agencies that regulate air quality in the region), echoed this sentiment when he described the passage of SB 375 as creating new forums for collaboration across organizational, jurisdictional, and issue-based boundaries.

I don't see that there's a place for folks to get together to collaborate... how do you make a big tent? Not if we're thinking just water and air, but when you get things like SB375 and sustainable communities, well, then...there's an entity that's now responsible, so it's got to bring all these folks together. (Personal communication with author, 2013).

To build this "big tent" social movement, environmental justice movements in the valley needed to build broader alliances than were common in their traditional environmental justice activism. To address the broader set of issues associated with SB 375, environmental justice advocates also had to reach out to organizations dedicated to agricultural land and habitat protection, smart growth, community economic development, and other interests.

Building a broad coalition required crossing racialized boundaries between environmental justice groups and traditional environmental organizations as the latter tend to be run by white people and focus on environmental protection, while the former are often run by people of color and focus on health impacts of environmental injustices (Greenlining Institute 2006). On the other hand, in their regional coalition-building task, environmental justice movements in the San Joaquin Valley had the advantage of building on existing alliances between local, regional, statewide and national organizations representing environmental justice organizations, mainstream environmentalists, public health advocates, and others in networks such as the 
Central Valley Air Quality Coalition (CVAQ 2015). This big-tent approach, described by one member as a "triumvirate" of environmental justice, environmental conservation, and public health organizations, thus brought different organizing approaches, bases of legitimacy, and social networks to bear on a commonly defined agenda.

Formalizing this multi-movement collaboration, in 2011 over 34 organizations, coordinated by two state-wide advocacy groups -- Climate Plan and the Leadership Council for Justice and Accountability -joined together to form the San Joaquin Valley Network. The network served as a regional forum for coordinating and, in some cases funding, activities by local coalitions in the valley's individual counties. It helped local activists form and enact a stronger collective regional identity. It also helped the regional coalition 'scale up' to advocate before the California Air Resources Board, urging it to use its authority to set more restrictive targets for reducing vehicle traffic and to approve SCSs that incorporated elements from the San Joaquin Valley Network agenda.

This latter strategy of appealing a higher authority might be described as "scale jumping" (Smith 2000). However, I argue, it may be better described as 'scale dancing', in which local, regional, state, and federal policy players not only move between existing scales, but enact new forms of environmental governance (Cohen and McCarthy 2015). In this way environmental justice advocates can be seen as promoting a new civic or insurgent regionalization project (Jones 2004, Paasi 1986, 2004) by inserting themselves into the dynamic relationship shaped by SB 375 between the San Joaquin Valley's local governments, county-scale COGs, and the California Air Resources Board.

To address the political and economic conservatism of local and county elected officials on the Valley's COGs, the San Joaquin Valley Network had to develop a language that emphasized the benefits of their proposals for creating jobs in the region. One planner in a Valley COG described her dilemma in this way:

This is a poor county, the majority of our members come from very poor communities, with huge unemployment rates. They want to know if there will be jobs. They want to know if they're going to get water, which is tied to jobs. So if I went in there and gave them a pitch on social equity, even though the majority of people might be people of color, they'd say what about the jobs? (Personal communication with author, 2013)

The San Joaquin Valley Network developed a campaign framework (2012a) called Seizing the opportunity: using the San Joaquin Valley Sustainable Communities Strategies to advance health, sustainability, and shared prosperity. The title speaks to the coalition's effort to embrace a broad cross-section of issues. Accordingly, its authors noted that "Regional Transportation Plans and Sustainable Communities Strategies can jumpstart the region's economy, save families money, improve public health, reduce air and water pollution, and strengthen the agricultural sector." The network expanded upon this framework in a 2012 letter to the San Joaquin Valley Regional Planning Agencies' Directors' Committee (San Joaquin Valley Network 2012b). This letter called on the planning directors to adopt strategies that prioritized investments to build out "complete communities" and to protect natural and agricultural landscapes as opposed to sprawl; public transit, walking, and biking routes as opposed to auto-dependent transportation systems; affordable and quality housing as opposed to gentrification and displacement.

With this playbook, advocates staged two distinct, but intersecting regional "games." The first was an "inside-out game" played within the formal public participation structures run by the Valley's COGs. Within these structures, the networks sought to represent the interests of the valley's most marginalized and underserved communities. They did this by joining regional committees, where they identified the environmental justice and social equity indicators and performance metrics that would be used to construct and assess the SCS planning scenarios, and by providing written and oral comments on the drafts of the planning documents. The second, "outside-in game", was performed outside these planning structures and drew on more confrontational social movement repertoires, such as letter-writing campaigns, organizing community members to pack public meetings, conducting behind-the-scenes lobbying with local elected officials, 
cultivating positive media attention, and working with legal advocates to prepare a litigation strategy to compel environmental justice-related policies as needed.

Expanding the topical scope of advocacy also demanded new sets of technical expertise. environmental justice movements in the San Joaquin Valley had developed expertise in air quality and water quality science and policy as well as litigation approaches. But engaging with SB 375 required expertise in complex approaches to land use and transportation planning and modeling. Toward this end, the San Joaquin Valley Network built its own expertise through careful study of the relevant planning methodologies. It also collaborated with a range of academic and consulting firm partners to conduct studies and develop analytical tools to inform and legitimize their policy agenda.

These tools included a range of environmental justice and social equity-focused analyses, including several studies of housing demand that recommended smaller infill developments over sprawling suburban land uses, all of which modeled the economic, health, environmental, and other impacts of the regional planning scenarios proposed by the San Joaquin Valley MPOs. Advocates drew on tools such as Urban Footprint and the Integrated Transport and Health Impacts Model (ITHIM) to project health implications of regional planning scenarios. In addition, the advocates used tools produced by the UC Davis Center for Regional Change (Karner et al. 2014). These tools included:

a) an environmental justice and regional equity analyses that highlighted the places where the highest concentrations of environmental hazards overlapped with the populations with low levels of economic, political, and social resources (London et al. 2011);

b) a Jobs-Housing Fit analysis that identified imbalances between the proximity of affordable housing and the accessibility of jobs for low-income households (Benner and Karner 2016);

c) a Health Impact Assessment methodology to measure the projected health implications of different SCS planning scenarios in disadvantaged communities (Garibay and Seaton 2014a, Garibay and Seaton 2014b).

The San Joaquin Valley Network used these and other tools to advocate for SCS scenarios that prioritized urban infill over suburban sprawl, public transit over new highways, the placement of affordable housing near jobs and essential services, and the revitalization of small rural communities inhabited largely by Latino farm workers and other low-income residents. It also advocated for more aggressive targets for reducing greenhouse gas emissions produced in the counties and the region as a whole. These regional scale proposals can be understood as what Kurtz (2002, 2003) would call "environmental justice scale counterframes" to the MPO regional planning scale frames, in that they inserted advocates' own sets of meanings and social equity values into the planning technologies used by the MPOs.

As a result of this organizing and advocacy, the San Joaquin Valley Network achieved several notable wins. In Fresno County, advocates organized as the Community Equity Coalition, worked with technical consultants to develop an equity and conservation-oriented SCS scenario which the COG later modeled and included in their list of planning options. While this alternative was ultimately not selected, several of its elements were incorporated, including directing some growth and transportation investment to existing rural communities inhabited by a majority of low-income people and people of color. The Fresno COG board also approved two of the network's campaign agenda items, namely: a needs-assessment process to identify urgent transportation and infrastructure needs in disadvantaged communities; and a new 'Sustainable planning and infrastructure' grant program to fund much-needed infrastructure improvements in existing low-income and mostly rural communities. In Kern County, the COG used the CRC's environmental justice analysis as part of its SCS. In San Joaquin County, advocates were also gratified to conclude that the final SCS aligned relatively well with their campaign platform. Notably, the COG shifted \$1 billion in funding originally allocated for new (sprawl-producing) roads and invested them in active transportation modes such as walking, biking, and public transit to serve disadvantaged communities (Knecht 2014). In sum, environmental justice and other regional advocates are now turning their attention in two directions: 'up' to the state as it sets new regional targets for the San Joaquin Valley for reducing greenhouse gas emissions; and 'down' to the city and county 
level, to track the implementation of SCSs with regard to land use, housing, and transportation. Environmental justice advocates' dynamic movement across this varied political terrain of the San Joaquin Valley can be understood as not merely championing one pre-existing regional scale over another, or one set of plans in an existing regional policy framework, but developing new regionalist identities and new configurations of regional governance.

\section{Conclusions}

I return now to the framing questions of the article: How can the concept of regions in the environmental justice and political ecology literature shed light on this case of regional planning in California's San Joaquin Valley? And how, vice-versa, can this concrete case shed light on the relationship between regions and the production of environmental and social inequality? Here I reference Paasi's useful analysis of the distinct, yet interrelated concepts of regions (things), regionalism (meanings/ identities), and regionalization (processes), a framework also elaborated by Neumann (2010) in his reflections on the role of regions in political ecology (Paasi 1986, 1991, 2004).

To start, conflicts can arise as different groups vie to define what a region actually is (Paasi 2004). In the San Joaquin Valley, disputes over the implementation of SB 375 were driven in part by the unsettled definition of the region in question. While SB 375 mandates regional planning by MPOs, in the San Joaquin Valley the local-control oriented county-level COGs have fragmented the planning arena in ways that make coordinated action to address the flows of automobile traffic in and through the region problematic. By contrast, the environmental justice movements and their allies represented some of the few champions for a truly San Joaquin Valley-wide regional planning approach that simultaneously met state mandates and sought to improved conditions in the Valley's most disadvantaged communities.

Second, it is clear that regionalism can have many faces depending on one's position in the system (Jones and MacLeod 2004, Pincetl, Jonas, and Sullivan 2011, Walsh 2004). In the case of the San Joaquin Valley, 'higher-up' California Air Resources Board California saw regionalism as a normative framework for climate change mitigation. To the 'lower-down' local governments and COGs in the San Joaquin Valley, regionalism was something to be resisted or at least cut down to county size. Environmental justice movements, by contrast, occupied a more fluid place between the 'local' and the 'middle', and embrace regionalism as a way to forge broader issue-based and geographic networks, while all the stretching to maintain the power and legitimacy they derive local-level organizing.

Third, regionalization involves multiple, contingent and contested processes (Jones 2001, 2004). Despite their resistance to regional-scale planning as mandated by the state, the Valley's eight COGs have, in fact, taken important steps to integrate their land use, transportation, and housing systems while also incorporating many elements advocated by environmental justice movements. These include expanding investments in existing, low-income rural towns, increasing public transit in urban core neighborhoods, and developing more meaningful and inclusive public participation processes that incorporate community knowledge and visions. How these policies will be put into action and how environmental justice advocates and public agencies engage with each other through the process remains to be seen.

Finally, understanding the "regionalness" (Hettne and Söderbaum 2000) of the San Joaquin Valley as a region in the making, enacted through the contested implementation of SB 375 offers political ecology and environmental justice scholars a complex but productive context in which to explore the place of regions in their respective fields. In particular, understanding the varied dimensions of San Joaquin Valley arising through the interactions between social movements and government entities helps illuminate how regional planning can produce and reproduce systems of social and environmental inequality, but it can also be a powerful force to disrupt, reimagine, and reconfigure them. 


\section{References}

Andrews, B.T. and S.K. Fairfax. 1983. Groundwater and intergovernmental relations in the Southern San Joaquin Valley of California: what are all these cooks doing to the broth? University of Colorado Law Review 55(2): 145-272.

Anguelovski, I. 2013. New directions in urban environmental justice: rebuilding community, addressing trauma, and remaking place. Journal of Planning Education and Research 33(2): 160-175.

Balazs, C.L. and R. Morello-Frosch. 2013. The three Rs: how community-based participatory research strengthens the rigor, relevance, and reach of science. Environmental Justice 6(1): 9-16.

Benner C. and A. Karner. 2016. Low-wage jobs-housing fit: identifying locations of affordable housing shortages. Urban Geography, in press

Benner, C. and M. Pastor. 2011. Moving on up? Regions, megaregions, and the changing geography of social equity organizing. Urban Affairs Review 47(3): 315-348.

Bickerstaff, K. and J. Agyeman. 2009. Assembling justice spaces: the scalar politics of environmental justice in north-east England. Antipode 41(4): 781-806.

Black, R. 1990. 'Regional political ecology' in theory and practice: a case study from Northern Portugal. Transactions of the Institute of British Geographers 15(1): 35-47.

Bulkeley, H. 2005. Reconfiguring environmental governance: towards a politics of scales and networks. Political Geography 24(8): 875-902.

Bulkeley, H., J. Carmin, V. Castan Broto, G.A.S. Edwards and S. Fuller. 2013. Climate justice and global cities: mapping the emerging discourses. Global Environmental Change 23(5): 914-925.

Bullard, R.D. 1990 (2000). Dumping in Dixie: race, class, and environmental quality. Boulder: Westview Press.

Cohen, A. and J. McCarthy. 2015. Reviewing rescaling: strengthening the case for environmental considerations. Progress in Human Geography 39(1): 3-25.

Cole, L.W. and S.R. Foster. 2001. From the ground up: environmental racism and the rise of the environmental justice movement. New York: New York University Press.

Faber, D. 2007. A more 'productive' environmental justice politics: movement alliances in Massachusetts for clean production and regional equity. In Sandler R. and P.C. Pezzullo (eds.) Environmental justice and environmentalism. Cambridge: MIT Press. Pp. 135-164.

Fujimoto, I. 2010. Dynamic mosaic: California Central Valley Partnership's collaborative multiethnic approach to organizing immigrant communities. PhD dissertation. Ithaca NY: Cornell University.

Garibay V. and P. Seaton 2014a. California's SB 375 and its Impact on Fresno County's Disadvantaged Unincorporated Communities and Low Income Urban Neighborhoods with Technical Assistance from The UC Davis Center for Regional Change and Policy Link.

Garibay V. and P. Seaton 2014b. California's SB 375 and its Impact on Kern County's Disadvantaged Unincorporated Communities and Low Income Urban Neighborhoodswith Technical Assistance from The UC Davis Center for Regional Change and Policy Link.

Goldschmidt, W.R. 1947. As you sow: three studies in the social consequences of agribusiness. Boston MA: Harcourt, Brace.

Greenlining Institute. 2006. Investing in a diverse democracy: foundation giving to minority-led nonprofits. Oakland CA: The Greenlining Institute.

Harrison, J.L. 2011. Pesticide drift and the pursuit of environmental justice. Cambridge: MIT Press.

Haslam, G.W. 1994. The other California: the Great Central Valley in life and letters. Reno: University of Nevada Press.

Hettne, B. and F. Söderbaum. 2000. Theorising the rise of regionness. New Political Economy 5(3): $457-472$. Heynen, N.C. 2003. The scalar production of injustice within the urban forest. Antipode 35(5): 980-998.

Holifield, R. 2012. Environmental justice as recognition and participation in risk assessment: negotiating and translating health risk at a superfund site in Indian Country. Annals of the Association of American Geographers 102(3): 591-613. 
Huang, G, and J.K. London. 2012. Cumulative environmental vulnerability and environmental justice in California's San Joaquin Valley. International Journal of Environmental Research and Public Health 9(5): 1593-1608.

Ikeme, J. 2003. Equity, environmental justice and sustainability: incomplete approaches in climate change politics. Global Environmental Change 13(3): 195-206.

Jermé E.S. and S. Wakefield. 2013. Growing a just garden: environmental justice and the development of a community garden policy for Hamilton, Ontario. Planning Theory and Practice 14(3): 295-314.

Jonas, A.E.G. 2013. Place and region III: alternative regionalisms. Progress in Human Geography 37(6): 822-828.

Jonas, A.E.G. and S. Pincetl. 2006. Rescaling regions in the state: the new regionalism in California. Political Geography 25(5): 482-505.

Jones, M. 2001. The rise of the regional state in economic governance: partnerships for prosperity' or new scales of state power? Environment and Planning A 33(7): 1185-1212.

Jones, M. and G. MacLeod. 2004. Regional spaces, spaces of regionalism: territory, insurgent politics and the English question. Transactions of the Institute of British Geographers 29(4): 433-452.

Karner, A., J.K. London, D. Rowangould and C. Garoupa-White. 2014. Putting data into action for regional equity in California's San Joaquin Valley. In Cytron, N., K.L.S. Pettit, G.T. Kingsley, D.J. Erickson and E.S. Seidman (eds.) What counts: harnessing data for America's communities. San Francisco: Federal Reserve Bank of San Francisco.

Knecht, C. 2014. Fresno and San Joaquin Counties adapt "Mementous" SCSes. Oakland: Climate Plan.

Krieg, E.J. and D.R. Faber. 2004. Not so black and white: environmental justice and cumulative impact assessments. Environmental Impact Assessment Review 24(7): 667-694.

Kurtz, H.E. 2003. Scale frames and counter-scale frames: constructing the problem of environmental injustice. Political Geography 22(8): 887-916.

London, J.K., M.L. Frampton, R. DeLugan, and I. Fujimoto. 2013. Growing community-university research partnerships in the San Joaquin Valley. Environmental Justice 6(2): 62-70.

London, J.K., G. Huang, and T. Zagofsky. 2011. Land of risk/ land of opportunity: cumulative environmental vulnerabilities in California's San Joaquin Valley. Davis: UC Davis Center for Regional Change.

London, J.K., T. Zagofsky, G. Huang, and J. Saklar. 2011. Collaboration, participation and technology: the San Joaquin Valley Cumulative Health Impacts Project. Gateways: International Journal of Community Research and Engagement 4: 12-30.

Lubell, M., R. Feiock, and S. Handy. 2009. City adoption of environmentally sustainable policies in California's Central Valley. Journal of the American Planning Association 75 (3): 293-308.

Mitchell, D. 1996. The lie of the land: migrant workers and the California landscape. Minneapolis: University of Minnesota Press.

Morello-Frosch, R., M. Pastor Jr., J. Sadd, C. Porras and M. Prichard. 2005. Citizens, science, and data judo: leveraging secondary data analysis to build a community-academic collaborative for environmental justice in Southern California. In Israel B.A., E. Eng, A.J. Schulz and EA. Parker (eds.) Methods in community-based participatory research for health. London: Wiley.

Nash, L.L. 2006. Inescapable ecologies: a history of environment, disease, and knowledge. Berkeley: University of California Press.

Neumann, R.P. 2010. Political ecology II: theorizing region. Progress in Human Geography. 34(3): 368-374.

Paasi, A. 1986. The institutionalization of regions: a theoretical framework for understanding the emergence of regions and the constitution of regional identity. Fennia-International Journal of Geography 164(1): 105-146.

Paasi, A. 1991. Deconstructing regions: notes on the scales of spatial life. Environment and Planning A 23(2): 239-256.

Paasi, A. 2003. Region and place: regional identity in question. Progress in Human Geography 27(4): 475485.

Paasi, A. 2004. Place and region: looking through the prism of scale. Progress in Human Geography 28(4): 536-546. 
Painter, J. 2002. Multi-level citizenship, identity and regions in contemporary Europe. In Anderson J. (ed.) Transnational democracy: political spaces and border crossings. London: Routledge.

Painter, J. 2008. Cartographic anxiety and the search for regionality. Environment and Planning A 40(2): 342361.

Pellow, D.N. 2007. Resisting global toxics: transnational movements for environmental justice. Cambridge: MIT Press.

Perkins, T.E. 2012. Women's pathways into activism rethinking the women's environmental justice narrative in California's San Joaquin Valley. Organization and Environment 25(1): 76-94.

Pincetl, S. 1994. The regional management of growth in California: a history of failure. International Journal of Urban and Regional Research 18(2): 256-274.

Pincetl, S. A.E. Jonas, and J. Sullivan. 2011. Political ecology and habitat conservation for endangered species planning in Southern California: region, places, and ecological governance. Geoforum 42(4): 427-438.

Pred, A. 1984. Place as historically contingent process: structuration and the time-geography of becoming places. Annals of the Association of American Geographers 74(2): 279-297.

Pulido, L. 1996. Environmentalism and economic justice: two Chicano struggles in the Southwest. Tucson: University of Arizona Press.

Pulido, L. and D. Peña. 1998. Environmentalism and positionality: the early pesticide campaign of the United Farm Workers' Organizing Committee, 1965-1971. Race, Gender and Class 6(1): 33-50.

Sadd, J.L., M. Pastor, R. Morello-Frosch, J. Scoggins, and B. Jesdale. 2011. Playing it safe: assessing cumulative impact and social vulnerability through an environmental justice screening method in the South Coast Air Basin, California. International Journal of Environmental Research and Public Health 8(5): 1441-1459.

San Joaquin Valley Network 2012a. Seizing the opportunity using the San Joaquin Valley Sustainable Communities Strategies to advance health, sustainability, and shared prosperity. [accessed October 10, 2015.]

San Joaquin Valley Network 2012b. Letter to the Regional Policy Council and San Joaquin Valley Regional Planning Agencies' Directors' Committee October 10, 2012.

Letter to the Regional Policy Council and San Joaquin Valley Regional Planning Agencies' Directors' Committee. October 10, 2012.

Saxton, D. 2015. Ethnographic movement methods: anthropology takes on the pesticide industry. Journal of Political Ecology 22: 368-388.

Scott, J.C. 1998. Seeing like a state: how certain schemes to improve the human condition have failed. New Haven: Yale University Press.

Smith, N. 2000. Scale. In R.J. Johnson, D. Gregory, G. Pratt, and M.J. Watts (eds.) The dictionary of human geography. Oxford: Blackwell. Pp.724-727.

Sze, J., J.K. London, F. Shilling, G. Gambirazzio, T. Filan and M. Cadenasso. 2009. Defining and contesting environmental justice: socio-natures and the politics of scale in the Delta. Antipode 41(4): 807-843.

Towers, G. 2000. Applying the political geography of scale: grassroots strategies and environmental justice. The Professional Geographer 52 (1): 23-36.

Walsh, C. 2004. Aguas Broncas: the regional political ecology of water conflict in the Mexico-US Borderlands. Journal of Political Ecology 11(1): 43-58. 